



\section{SOME PROBLEMS IN GREENHOUSE INSPECTION WORK IN INDIANA}

Br Harry F.Dietz, Department of Conservation, Indianapolis ${ }^{1}$

The total value of the greenhouses of the United States is between $\$ 75,000,000$ and $\$ 100,000,000$. In Indiana alone there are $4,500,000$ square feet of ground covered by greenhouses conservatilvey valued at $\$ 5,000,000$. Our State ranks seventh among the commercial flowergrowing states of the Union, being surpassed only by New York, Pennsylvania, New Jersey, Illinois, Massachusetts, and Ohio. Little thorough work relating to the life history and control of the most common and destructive of these insect pests or plant diseases has been done. The florists have been left largely to shift for themselves and to devise control methods good, had, and indifferent. Generally only in cases where the destruction of an entire crop has been threatened, through the spread of a serious pest such as the chrysanthemum midge, have entomologists as a whole äided the florists.

The problems arising in the inspection and certification of greenhouse plants for intra and inter state shipment have not been given the careful and thorough consideration they deserve. The writer does not presume to say how these problems should be dealt with, but will point out and illustrate by specific cases, the problems that have arisen in Indiana in order to awaken an interest in the matter.

${ }^{1}$ Published with the permission of the Director of the Department of Conservation and the Chief of the Division of Entomology. 
It is necessary here to point out that there is a very important difference between greenhouse grown plants and nursery stock at the time each is distributed. Nursery stock is dormant when shipped. The leaves are off and practically all soil is removed from the roots. There are some exceptions as in the case of conifers and other evergreen plants. On the other hand plants grown under glass are generally shipped in a growing condition. Except in the case of cuttings and bud-wood, defoliation is out of the question and so is the removal of soil from the roots. Therefore, any insect or disease attacking the leaves, stems, or roots, are generally carried with the plants.

The first problem is, "What shall we regard as 'clean' plants?"-in other words, "What are plants free from dangerously injurious insects and plant diseases?" The following list of greenhouse insects (including mites) and plant diseases has been arranged in accordance with the prevalence of the pests in Indiana greenhouses (See p. I90).

It is evident that many of the tropical and sub-tropical insects, such as the mealy-bugs and scale insects listed, are serious pests in California and Florida and along the Gulf of Mexico; therefore, their very presence in a greenhouse ought to be sufficient grounds for refusing the grower a permit to ship plants to the regions mentioned. The terminal inspection systems in use in California and Florida will prevent infested stock from entering these states. Yet, should the presence of these pests warrant the refusal of a permit to ship when the plants are grown for northern distribution only, and where perhaps the only persons who will have trouble with them will be florists and their patrons? This distribution of, in most cases lightly infested, plants from florist to florist and from florist to patron has lead to some interesting results. Ten years ago the coleus was one of the most popular bedding plants in Indiana. But today that popularity lias decreased so far that few florists grow this plant, and all this is due to mealy-bugs. The florists could not, or did not, keep these plants free from the pest with the result that when the plants were bedded out with others during the summer it was only a matter of time until the other plants, as well as the coleus, were infested and the bed ruined. The patrons of the florist liave learned that the coleus is a plant not to buy because of the danger of their being infested with mealy-bugs.

Many Indiana florists have also discontinued the growing of palms and other subtropical plants used for decorative purposes because of the difficulty they have had in controlling the tropical and subtropical scale insects attacking them. Ten years ago a greenhouse was incomplete without a stock of palms and other tropical decorative plants. Such plants usually went from bad to worse year by year and as they died

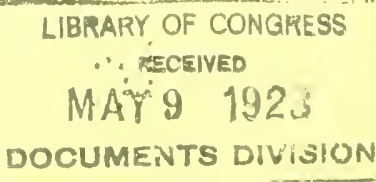




\section{INSECT PESTS INCLUDING MITES}

\begin{tabular}{l}
\hline Pest \\
\hline Red Spider (Tetranychus telarius Linn.)1 \\
$\begin{array}{l}\text { Mealy Bugs (Pseudococcus citri Risso and P. } \\
\text { adonidum Linn.) }\end{array}$ \\
$\begin{array}{l}\text { Greenhouse White Fly (Tialeurcdes vaporariorum } \\
\text { Westu })^{2}\end{array}$ \\
$\begin{array}{l}\text { Greenhouse Thrips (Iteliothrips haemorhoidalis } \\
\text { Bouché }\end{array}$ \\
\hline
\end{tabular}

Plant Lice

Boston Fern Scale (Hemichionaspis aspidistrae Sign. ${ }^{2}$

Chrysanthemum Midge (Diarthronomyia hypogaea F. I,w.)2?

Greenhouse Lcaf-tier (Phlycluenia ferrugalis Hubn.) 1

Rose Midge (Dasyneura [Neocerata] rhodophaga Coq.) ${ }^{2}$ ?

Rose or Oblique-banded Leaf-roller (Archip [Cacoecia] rosaceana Harr.)1

F]orida Fern Worm (Eriopus [Callopistria] floridensis (ruen.) ${ }^{2}$

Soft Scale (Coccus hesperidum Linn.) ${ }^{2}$

Hemispherical Scale (Saissetia hemisphaerica Targ.)

Oleander Scale (Aspidiotus hederae Vall. $)^{2}$

Florida Red Scale (Chrysomphalus conidum Linn.) ${ }^{2}$

Boisduval's scale (Diaspis boisduvalii Sign.)2

Strawberry Root-norm (Paria canella Fabricius vars. alerrima Oliv. and quadrigullatus Lec.)! Cyclamen Mite (Tarsonemus pallidus Banks)2?

Chaff Scale (Parlatoria proteus Curt.) ${ }^{2}$

The Crazy Ant (Prenolepis longicornis Latr.) 2

The Greenhouse Orthezia (Orthesia insignis Dougl.) 2

The Argentine Ant (Iridomyrmex humilis Mavr)2

Disease

Root and Stem Rot (Rhisocionia sp.)

Wilt, Stem Rot or Die Back (Fusarium sp.)

Carnation Rust (Uromyces caryophillinus [Schrank] Winter)

Bud rot (Sporotrichum poae Peck)

Wilt (Fusarium sp.)

Anthracnose (Gloeosporium rosae Halsted)

Cane Blight (Coniothyrium fuckelii Saccardo)

Crown Gall (Bacterium tumefaciens Erw. Smith and Townsend)

Rust (Puccinia anthirrini Dietel and Holway)

\section{Host on which it may be distributed}

Roses, carnations, chrysanthemums, smilax, palms, aspidistra, etc.

Coleus, geraniums, palms, rubber plants, Boston and related ferns, dracenas, etc.

Pelargonium, fuchsia, primulas, celestial peppers and ornamental solanums.

Rose, carnation, chrysanthemum, croton, aspidistra, Ficus spp. azalea, etc.

Aphis rufomaculata Wilson and Macrosiphum sanbcrni Gill. on chrysanthemums ${ }^{1}$; Macrosiphurl rosae Linnaeus on rosel. Mysus persicae Sulzer on carnations ${ }^{1}$; A phis sossypii Glover on begonias, Easter lilies??, Cerataphis lataniae Bdv. on Kentia palms. ${ }^{2}$

On Boston and other ferns, aspidistra.

Species and varicties of the genus Chrysanthemum

Chrysanthemum, cineraria, primulas, carnation. rose.

Roses.

Rose, carnation

Various genera, species and varicties of greenhouse ferns.

Ferns, palms, crotons, ornamental citrus plants, camellia, Ficus spp., bay trees, orchids, etc.

Same as Soft Scale.

Palms, cycads, ornamental citrus plants, orchids, bay trees, Olea fragrans. etc.

Palms, Ficus spp., ornamental citrus plants, Pandanus veitchi, Dracena indivisa, aspidistra, cypripediums.

Paims, orchids (Cattleya spp.).

Roses? Soil (larvae).

Geranium, cyclamen, chrysanthemums, snapdragons.

Ornamental citrus plants, orchids (Vanda spp.).

In peat around orchids (Callleya spp. and Vanda spp.) Only one record from Indiana.

Coleus. Only one record from Indiana greenhouses, other hosts are lantana, verbena, chrysanthemum, gardenia.

Pandanus, dracena, dieffenbachia, and aspidistra See text p. I03 for a discussion of this insect. Has not been found in Indiana.

Host on which it may be distributed

Carration.
Carnation.
Carnation.
Carnation.
Chrysanthemum.
Rose.
Rose.
Rose.
Snapdragon.

Holartic insects

${ }^{2}$ Tropical or semitropical insects. 
were replaced by others. Infested plants served as a harbor for scale insects and a source from which plants like ferns, which were often grown in the same house, became infested. When a florist sold a palm or similar plant he often got it back during the winter as a "boarder." Often he took it back in spite of his better judgment and set it among his own plants which he had fought hard to keep clean. In view of these facts should the grower who takes in "boarders," which are generally scale infested, be allowed to ship plants to another grower in another state who does the same thing? Or, if not, to what treatment should lightly infested plants be subjected to kill any infestation of scales or other insects occurring on thein?

Ferns are delicate plants and when they become infested with insects it is practically impossible to "clean them up" without injuring the plants. Hence, what disposition should an inspector make in the case of ferns that show a very slight and scattered infestation of ary of such scale insects as the soft scale, the hemispherical scale, or the Boston fern scale? It is needless to point out that a grower of ferns free from these insects is always afraid of introducing these pests on plants he buys. One florist in a small Indiana city bought several thousand fern plants infested with soft scale from a large grower and distributor in another state. These he unwittingly set among his clean stock with rather disastrous results. How can occurrences like this be best prevented?

The rapid spread of the chrysanthemum midge shows what may happen when a serious greenliouse pest becomes established in the greenliouses of one or more large growers. In 1914 it was known only from the houses of one large chrysanthemum grower, but by 1917 eight of the large distributors in widely separated parts of the United States had serious infestations. Fortunately we know now how to control the insect and most of the larger growers in Indiana have it under absolute control and several have practically exterminated the pest in their greenhouses. Nevertheless, its spread is continuing. In 1916 when widespread warnings were disseminated many of the smaller growers, such as local florists, became frightened and refused to buy mum plants for two or three years. But during the spring of 1919 and 1920, lead on by the high price of cut flowers, many florists "plunged" heavily on mums. Even those who bought only such plants as they needed of some new and popular variety often got the midge with them. One large distributor got an infestation in this manner. He fortunately did not buy any chrysanthemum plants from 1914 to 1919 and as a result had no midge. In 1919 he bought 200 plants of a new variety and luckily escaped the pest. But in 1920 he bought 250 plants of a 
new variety from a jobber and with them came a light infestation so that this fall not only the plants he bought but two of his own varieties were infested slightly.

In many respects the rose midge is like the chrysanthemum midge. Though this insect has been known in the United States since 1887, its ottbreaks have been more or less sporadic and probably dependent on the distribution of new varieties which have served as favorite food plants. The last distribution and resulting outbreaks of this pest took place with the dissemination of the popular rose, Ophelia. There is little doubt but that the plants, sent out by one of the several distributors of this variety, were infested with this midge. Ophelia is a fine seed parent and also shows a tendency to "sport" easily. Many of its "sports" and seedling offspring are held in high esteem by the florists and are constantly gaining in poptlarity with the flower-buying public. The reason I have mentioned this fact is that Indiana observations indicate that some of these sports and seedlings show the same susceptibility to the attacks of rose midge that their parent does and there are indications that another outbreak of this insect over wide areas is going to result.

The greenhouse white fly, because of the range of host plants it attacks, is very troublesome. It is difficult to control, especially when hydrocyanic acid gas is not used. Florists who have not had expericnce with this insect often scoff at the idea that it is a serious pest. But many Indiana florists have changed their minds regarding its inportance. Those who have attenpted to grow semi-hardy perennials like buddleia and bouvarlia under glass or those who have lost a crop of indoor asters through its attack do not think it a pest of secondary importance. Those who grow fuschias, salvias, primulas and celestial peppers know that it is no easy task to control white fly. Yet one can find growers of some of its favorite food plants who have little or no difficulty in holding the insects in check, often without resorting to cyanicle fumigation. In view of these facts what disposition should an inspector make of plants lightly infested with white fly?

Those insects and mites that occur out-of:doors in the northern twothirds of the United States but have invaded greenhouses, like the red spider, the greenhouse leaf-tier, the rose leaf-roller, and the strawberry root-rvorm, present an interesting case. The first and the last named become serious pests out-of-dnors but the other two do not seem to be nearly as serious pests in the open as under glass. If Indiana experiences are to be taken as a basis, it is safe to assume that both the leaf-tier and leaf-roller have been far more widely distributed through the medium of infested hosts than through the invasion of the greenhouses by moths, 
or caterpillars, in widely separated localities. We have noticed that when any large grower and distributur has an outbreak of these two pests it is not long before a number of the smaller growers who have bought from the infested source have an outbreak. Hence, shall the presence in a greenhouse of any of these insects mentioned, even though they are being held in check successfully, warrant the withholding of a certificate of inspection?

The tropical ants are pests that seem to be gaining a foothold in our northern greenhouses. One of our florists bought a large collection of orchids from a jobber. With these he got the following insect pests,a heavy infestation of Parlatoria pergandii Comst. on vandas, a heavy infestation of Diaspis boisduralii Sign. on cattleyas and a scattering infestation of Coccus psendohesperidum Ck11. and Targionia biformis Ck11. (both new coccid records for Indiana) on the same host. But what is probably more important than all these scale insects, he got a heavy infestation of the crazy ant-Prenolepis longicornis Latr. with nests in the peat in which the orchids were growing. Just what the outcome of its introduction into this Indiana greenhouse will be, remains to be seen. What action should the state in which this shipment originated have taken? And what action should the State of Indiana take to prevent the further distribution of this insect?

It is a common thing for Indiana florists to buy plants like aspidistra, ficus, Dracena indivisa and Pandanus veitchii that have been grown outof-doors (or with slight protection in the winter) in the southern states. I was amazed to find that the greenhouses where a large southern distributor of aspidistras grew these plants were alive with the Argentine ant. What action should be taken to prevent the spread of this insect, northward?

Though comparatively little is known about greenhouse insects, far less is known about most of the diseases attacking plants grown under glass. There is carnation rust, the Fusarium root rot, and the Rhizoctonia branch and stem rot on this host. There is the snapdragon rust which has spread over the whole United States in the past twenty years. The widespread distribution of this disease might at one time have been checked. On roses we have such diseases as anthracnose and cane blight. There are doubtless many others which will attract attention following intensive study. Should the presence of any of the diseases mentioned in a greenhouse warrant the withholding of a certificate of inspection? Can infected plants be sent under a qualified certificate of inspection? Are these diseases dangerously injurious?

At present, three alternatives are open to state inspectors relative to plants grown under glass. The first is to let any and all persons who 
desire to ship greenhouse plants do so on the grounds that such plants do not come under the regular nursery inspection requirements. Technically this view is correct. The second alternative is to inspect the plants and issue a certificate if the plants are free from insect pests and plant diseases at the time of inspection and if measures are being taken by the grower to keep them so. The third alternative is to issue qualified certificates of inspection provided there are no dangerously injurious insects or diseases present or new and uncommon ones which are very restricted in their distribution. Certain combinations of these three alternatives are in use in some states. In these cases if a grower is refused a certificate of inspection he can ship his plants by merely attaching a statement to them that they are greenhouse grown and are thus exempt from inspection. Thus the man who grows clean stock for distribution is at a disadvantage in that he must compete with the one who does not. Also in such cases anyone who wants to sell greenhouse plants, no matter how badly they are infested with insects or infected with diseases, can sell them and there is nothing in most states that will protect the buyer of these plants except the contract he has with the man from whom he is buying.

Now if the certification of greenhouse plants is undertaken what shall the basis of such certification be? How often and when shall the plants be inspected? Thirty days will often change the entire aspect of the insect and disease conditions in greenhouses. If there is but a single inspection when shall that be? The presence of the rose midge may not even be suspected if an inspection is made from December to March. Chrysanthemum midge, especially where a light infestation occurs, might be overlooked if the inspection were made during the summer, from the last of June to the first of October. During the months from December to April only the most careful inspection would reveal the occurrence of the strawberry root-worm.

In general, it might be said that two inspections, one in the summer and one in the winter, ought to give the inspector a good idea not only of the insect and disease conditions in a given greenhouse but also an idea of the grower's ability to "clean up" his plants and keep them so. 
LIBRARY OF CONGRESS

|| || || || || || ||||||||||||||||||

00214896667 

